\title{
Long-term mechanical circulatory support: A new disease state?
}

\author{
Hari R. Mallidi, MD, Jatin Anand, MD, and Steve K. Singh, MSc, MD
}

See related article on pages e11-2.

The use of ventricular assist device (VAD) therapy has markedly increased over the past decade. Compared with first-generation pulsatile pumps, patients with contemporary continuous-flow VAD implants are living longer and with significantly improved outcomes.

With thousands of patients alive on mechanical circulatory support, complications will inevitably occur with a higher prevalence. Issues such as pump thrombosis, inlet malposition, outflow graft obstruction, infections, gastrointestinal bleeding, strokes, and other serious complications are still incompletely understood (Figure 1). Heart failure specialists will be needed to better understand the basic pathophysiology, to evaluate patient outcomes, and to develop optimal management practices as our collective experience with these problems expands.

The current report describes a novel therapeutic approach to the infrequent yet serious problem of outflow graft obstruction. Problems with outflow grafts have been described and include kinking caused by bend relief malfunction, ${ }^{2}$ pump malposition, ${ }^{3}$ or pump migration ${ }^{4}$; obstruction due to thrombus ${ }^{5}$ or infectious growth ${ }^{6}$; and pseudoaneurysm formation due to infection or erosion of adjacent structures into the graft.

For patients experiencing such complications, options are limited. For the select few who have sufficient myocardial recovery, pump explantation may be an option. This can be performed using a minimally invasive technique with ligation and retention of a small remnant of the outflow graft. ${ }^{8}$ When ongoing support is necessary, surgical revision with potential pump replacement may be required.

Pham and colleagues ${ }^{10}$ describe the use of percutaneous radial artery catheterization with aortography and outflow graft cannulation for the diagnosis of an outflow graft obstruction alleviated successfully by the placement of a balloon-expandable stent graft. The current report is an

From the Division of Transplant and Assist Devices, Department of Surgery, Baylor College of Medicine, Houston, Tex.

Disclosures: Authors have nothing to disclose with regard to commercial support.

Received for publication April 16, 2015; accepted for publication April 17, 2015.

Address for reprints: Hari R. Mallidi, MD, One Baylor Plaza, Houston, TX 77030

(E-mail: mallidi@bcm.edu).

J Thorac Cardiovasc Surg 2015;150:e13-4

$0022-5223 / \$ 36.00$

Copyright (C) 2015 by The American Association for Thoracic Surgery

http://dx.doi.org/10.1016/j.jtcvs.2015.04.049

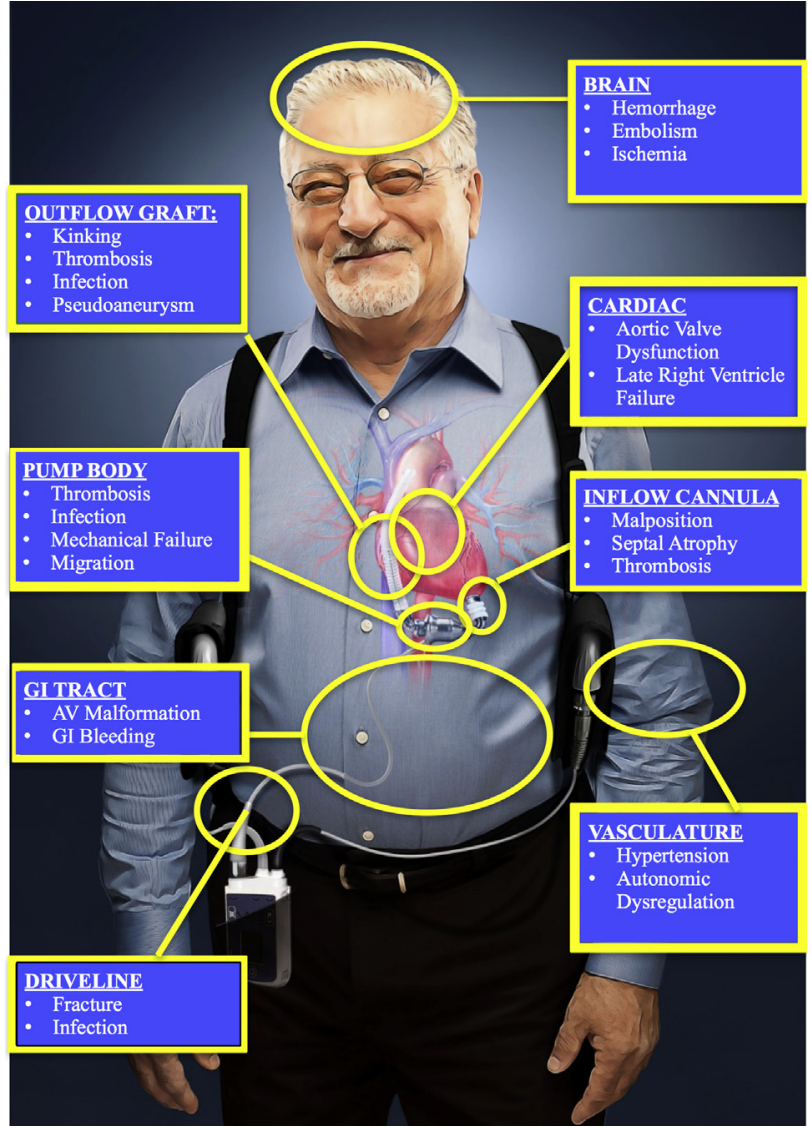

FIGURE 1. Continuous-flow left ventricular assist device in situ demonstrating potential complications throughout the body. $A V$, Atrioventricular; GI, gastrointestinal.

important contribution to the field because it stresses the fact that each complication presents an opportunity for novel therapeutic intervention, which may include the use of existing technologies for previously unrealized indications. This further emphasizes the importance of a multidisciplinary approach to all aspects of patient care. These less-invasive approaches to mitigate iatrogenic complications will allow more patients to achieve longterm success with their new and incompletely understood VAD-induced physiology.

\section{References}

1. Kirklin JK, Naftel DC, Pagani FD, Kormos RL, Stevenson LW, Blume ED, et al Sixth INTERMACS annual report: a 10,000-patient database. J Heart Lung Transplant. 2014;33:555-64.

2. Yuzefpolskaya M, Uriel N, Chow DS, Restaino SW, Mancini DM, Flannery M, et al. Prevalence and timing of bend relief disconnection in patients supported by the late version HeartMate II left ventricular assist device. J Heart Lung Transplant. 2013;32:320-5. 
3. Taghavi S, Ward C, Jayarajan SN, Gaughan J, Wilson LM, Mangi AA. Surgical technique influences HeartMate II left ventricular assist device thrombosis. Ann Thorac Surg. 2013;96:1259-65.

4. Adamson RM, Mangi AA, Kormos RL, Farrar DJ, Dembitsky WP. Principles of HeartMate II implantation to avoid pump malposition and migration. J Card Surg. 2015;30:296-9.

5. Rose AG, Connelly JH, Park SJ, Frazier OH, Miller LW, Ormaza S. Total left ventricular outflow tract obstruction due to left ventricular assist deviceinduced sub-aortic thrombosis in 2 patients with aortic valve bioprosthesis. $J$ Heart Lung Transplant. 2003:22:594-9.

6. Maly J, Szarszoi O, Dorazilova Z, Besik J, Pokorny M, Kotulak T, et al. Case report: atypical fungal obstruction of the left ventricular assist device outflow cannula. J Cardiothorac Surg. 2014;9:40.
7. Ganapathi AM, Andersen ND, Prastein DJ, Hashmi ZA, Rogers JG, Milano CA, et al. Endovascular stent grafting of a left ventricular assist device outflow graft pseudoaneurysm. Circ Heart Fail. 2013;6:e16-8.

8. Frazier $\mathrm{OH}$, Baldwin AC, Demirozu ZT, Segura AM, Hernandez R, Taegtmeyer $\mathrm{H}$, et al. Ventricular reconditioning and pump explantation in patients supported by continuous-flow left ventricular assist devices. J Heart Lung Transplant. 2015;34:766-72.

9. Cohn WE, Mallidi HR, Frazier OH. Safe, effective off-pump sternal sparing approach for HeartMate II exchange. Ann Thorac Surg. 2013;96: 2259-61.

10. Pham DT, Kapur NK, Dermody M, Halin N. Stenting of an outflow graft obstruction after implantation of a continuous-flow, axial-flow left ventricular assist device. J Thorac Cardiovasc Surg. 2015;150:e11-2. 